\title{
AKUNTABILITAS KEPEMIMPINAN PADA KEPENDIDIKAN BERBASIS AGAMA ISLAM
}

\author{
Sutarman \\ amrisutarman@yahoo.com, \\ (Dosen STKIP SERA dan STMIK Triguna) \\ Agus Salim, Ujang Cepi Barlian \\ bani.samudra@gmail.com \\ (Dosen Fakultas Agama Islam Universitas Muhammadiyah Tangerang)
}

\begin{abstract}
Abstrak:
Akuntabilitas kepemimpinan pada tenaga kependidikan berbasis agama merupakan elemen terpenting dalam pendidikan. Pendidikan yang berkualitas dapat diwujudkan apabila sekolah memiliki pemimpin dan tenaga pengajar yang berkualitas serta memiliki komitmen dan integritas yang tinggi untuk memajukan pendidikan yang berkualitas.. Ada empat komponen utama yang dapat dijadikan kriteria umum sebagai acuan untuk meneningkatkan kualitas pada sebuah lembaga kependidikan, yang meliputi (1) pembelajaran peserta didik (2) kesempatan untuk belajar, (3) responsif terhadap peserta didik, orang tua, dan masyarakat, (4) kapasitas kemampuan dalam perbaikan lembaga pendidikan.
\end{abstract}

\section{Kata kunci : Akuntabilitas, Kepemimpinan, Kependidikan}

\section{A. Pendahuluan}

Penyelenggaraan manajemen pendidikan yang memenuhi prinsip akuntabilitas, tampaknya masih melewati jalan panjang, dan berliku-liku. Walaupun tuntutan akan manajemen pendidikan yang akuntabel terus disuarakan banyak pihak, belum semua aparatus pendidikan menyambutnya. Ini sangat berkaitan dengan persoalan kemauan, kemampuan, persepsi, kepercayaan. Karena itu makalah ini ditulis untuk melanjutkan proses mengurai benang kusut yang hampir putus itu. Uraian disandarkan pada pengertian akuntabilitas pendidikan, tujuan akuntabilitas pendidikan, manfaat akuntabilitas pendidikan, pelaksana akuntabilitas pendidikan, pelaksanaan akuntabilitas pendidikan, langkah-langkah akuntabilitas pendidikan, faktor-faktor yang mempengaruhi akuntabilitas pendidikan, dan upaya peningkatan akuntabilitas pendidikan. Nilai dan kultur, serta matinya perasaan terdesak menjadi faktor penghadang di depan. Tetapi hanya dengan kemauan dan visi perubahan niscaya prinsip akuntabilitas. ${ }^{1}$ dapat membumi di sekolah.

\section{B. Pembahasan}

1. Pengertian Akuntabilitas Pendidikan Menurut; Mc. Ashan (1983) ${ }^{2}$ menyebutkan bahwa akuntabilitas adalah kondisi seseorang yang dinilai oleh orang lain karena kualitas performannya dalam

\footnotetext{
${ }^{1}$ Harus jujur, objektif, transparan dan inovatif sebagai katalisator perubahan manajemen instansi pemerintah dalam bentuk pemutakhiran metode dan teknik pengukuran kinerja dan penyusunan laporan akuntabilitas. Selain prinsip-prinsip tersebut, akuntabilitas kinerja harus juga menyajikan penjelasan

${ }^{2}$ Akuntabilitas Pendidikan Mc.Ashan (1983)menyebutkan bahwa akuntabilitas adalah kondisi seseorang yang dinilai oleh orang lain karena kualitas performannya dalam menyelesaikan tujuan yang menjadi tanggungjawabnya. Sedangkan John Elliot (1981: 15-16) merinci makna yang terkandung di dalam akuntabilitas,
} 
menyelesaikan tujuan yang menjadi tanggung jawabnya. Sedangkan menurut; John Elliot (1981:15-16) ${ }^{3}$ merinci makna yang terkandung di dalam akuntabilitas, yaitu:

a. Cocok atau sesuai dengan peranan yang di harapkan,

b. Menjelaskan, mempertimbang kan kepada orang lain tentang keputusan dan tindakan yang di ambilnya,

c. Performan yang cocok dan dan meminta pertimbangan/penjelasan kepada orang lain.

Akuntabilitas membutuhkan aturan, ukuran atau kriteria, sebagai indikator keberhasilan suatu pekerjaan atau perencanaan. Dengan demikian, maka akuntabilitas adalah suatu keadaan performan para petugas yang mampu bekerja dan dapat memberikan hasil kerja sesuai dengan kriteria yang telah di tentukan bersama sehingga memberikan rasa puas pihak lain yang berkepentingan. Sedangkan akuntabilitas pendidikan adalah kemampuan sekolah mempertanggung jawab kan kepada publik dalam segala sesuatu mengenai kinerja yang telah dilaksanakan.

Menurut; Scorvis D. Anderson, ${ }^{4}$ and Whither Dalam kutipan Made Pidarta, menyebutkan lima bagian yang merupakan manifestasi dari akuntabilitas, yaitu:

a. Mengontrak performan. Performan di tentukan kriterianya dan disepakati bersama. Artinya pertugas pelaksana tidak boleh menyimpang dari kriteria tersebut.

${ }^{3}$ Akuntabilitas Pendidikan Elliot (1981: 1516) Pengertian Akuntabilitas Pendidikan. McAshan (1983) menyebutkan bahwa akuntabilitas adalah kondisi seseorang yang dinilai oleh orang lain karena kualitas performannya dalam menyelesaikan tujuan yang menjadi tanggungjawabnya. Sedangkan John Elliot (1981: 15-16) merinci makna

${ }^{4}$ Scorvis D. Anderson and Whither Dalam kutipan Made Pidarta dalam bukunya Accountability What, Who, and Whither (1988) b. Memiliki kunci pembentuk arah dalam bentuk biaya dan usaha performan yang dikontrak/ditentukan, diharapkan tercapai tujuan secara efektif sehingga pengontrak merasa puas.

c. Unsur pemeriksaan yang dilakukan oleh orang-orang bebas dan tidak terlibat dalam kegiatan internal, seperti orang tua siswa, masyarakat, atau pemerintah.

d. Memberikan jaminan, dalam bidang pendidikan mutu dapat terjamin dengan menggunakan kriteria atau ukuran tertentu.

e. Pemberian insentif, diberikan sebagai penghargaan dan dapat di ukur menurut kriteria tertentu, dengan maksud untuk meningkatkan motivasi dan sistem kompetisi dalam meningkatkan performan.

Menurut H. H. Mc Ashaan, yaitu: ${ }^{5}$

a. Program dan manajemen personalia yang mengarah kepada tujuan,

b. Penekanan manajemen yang efektif dan efisien, dan

c. Pengembangan program, pengembangan personalia, peningkatan hubungan dengan masyarakat, dan kegiatan-kegiatan manajemen.

Tujuan akuntabilitas pendidikan adalah agar terciptanya kepercayaan publik terhadap sekolah. Kepercayaan publik yang tinggi akan sekolah dapat mendorong partisipasi yang lebih tinggi pula terdapat pengelolaan manajemen sekolah. Sekolah akan dianggap sebagai agen bahkan sumber perubahan masyarakat. Slamet (2005:6) menyatakan: Tujuan utama akuntabilitas adalah untuk mendorong terciptanya akuntabilitas kinerja sekolah

${ }^{5}$ Kepercayaan publik yang tinggi akan sekolah dapat mendorong partisipasi yang lebih tinggi pula terdapat pengelolaan manajemen sekolah. Sekolah akan dianggap sebagai agen bahkan sumber perubahan masyarakat. Slamet (2005: 6) 
sebagai salah satu syarat untuk terciptanya sekolah yang baik dan terpercaya. Penyelenggara sekolah harus memahami bahwa mereka harus mempertanggung jawabkan hasil kerja kepada publik. Selain itu, tujuan akuntabilitas adalah menilai kinerja sekolah dan kepuasaan publik terhadap pelayanan pendidikan yang diselenggarakan oleh sekolah, untuk mengikutsertakan publik dalam pengawasan pelayanan pendidikan dan untuk mempertanggungjawabkan komitmen pelayanan pendidikan kepada publik. akuntabilitas bukanlah akhir dari sistem penyelenggaran manajemen kependidikan, tetapi merupakan faktor pendorong munculnya kepercayaan dan partisipasi dari semua steak holder. karena akuntabilitas sebagai titik awal keberlangsungan dalam mengelola pendidikan.

Pengawasan merupakan fungsi manajemen diperlukan agar tujuan yang hendak dicapai bisa tercapai, efisien dan efektif, di dalam Islam, fungsi pengawasan termaktud pada al-Qur'an surat As-Shof ayat $3:^{6}$ "Amat besar kebencian di sisi Allah bahwa kamu mengatakan apa-apa yang tidak kamu kerjakan." Ayat tersebut memberikan ancaman dan peringatan terhadap orang yang mengabaikan pengawasan terhadap perbuatannya. Selain ayat tersebut, terdapat juga pada QS, AlSajdah, ayat 5.' 'Dia mengatur urusan dari langit ke bumi, kemudian (urusan) itu naik kepada-Nya dalam satu hari yang kadarnya adalah seribu tahun menurut perhitunganmu.

${ }^{6}$ Al-Qur'an surat As-Shof ayat 3, Tafsir Qur'an perkata Maghfirah Pustaka 2006 (Abu abas menjelaskan bahwa kedua ayat ini diturunkan berkenaan dengan sebagian orang mukmin yang enggan melakukan jihad meskipun telah mengetahui bahwa berjihad seperti yang tersebut pada quran $61 ; 11$

${ }^{7}$ QS, Al-Sajdah, ayat 5. Tafsir Qur'an perkata Maghfirah Pustaka 2006
Kandungan ayat di atas menjelaskan bahwa Allah SWT adalah pengatur alam. Keteraturan alam raya ini, merupakan bukti kebesaran Allah swt dalam mengelola alam ini. Namun, karena manusia yang diciptakan Allah SWT telah dijadikan sebagai khalifah di bumi, maka dia harus mengatur dan mengelola bumi dengan sebaik-baiknya sebagaimana Allah mengatur alam raya ini. Sejalan dengan kandungan ayat tersebut, manajemen merupakan sebuah proses pemanfaatan semua sumber daya melalui bantuan orang lain dan bekerjasama dengannya, agar tujuan bersama bisa dicapai secara efektif, efesien, dan produktif. Fungsi manajemen adalah merancang, mengorganisasikan, memerintah, mengkoordinasi, dan mengendalikan. Sejalan dengan ayat di atas, Allah Swt memberi arahan kepada setiap orang yang beriman untuk mendesain rencana apa yang akan dilakukan dikemudian hari, sebagaimana Firman-Nya dalam Al-Qur'an Surat Al Hasyr: 18: "Wahai orang-orang yang beriman, bertaqwalah kepada Allah dan hendaklah setiap diri memperhatikan apa yang telah diperbuatnya untuk hari esok (akhirat); dan bertakwalah kepada Allah, sesungguhnya Allah Maha Mengetahui apa yang kamu kerjakan.

Beberapa hadits Rasulullah Saw juga menganjurkan perlunya melaksanakan pengawasan atau evaluasi dalam setiap pekerjaan. Ajaran Islam sangat memperhatikan adanya bentuk pengawasan terhadap diri terlebih dahulu sebelum melakukan pengawasan terhadap orang lain. Hal ini antara lain berdasarkan hadits Rasulullah Saw sebagai berikut: "Periksalah dirimu sebelum memeriksa orang lain. Lihatlah terlebih dahulu atas kerjamu sebelum melihat kerja orang lain." (HR. Tirmidzi: 2383).

${ }^{8}$ Al-Qur'an Surat Al Hasyr: 18 Tafsir Qur'an perkata Maghfirah Pustaka 2006 
Dalam pandangan Islam segala sesuatu harus dilakukan secara terencana, dan teratur. Tidak terkecuali dengan proses kegiatan belajar-mengajar yang merupakan hal yang harus diperhatikan, karena substansi dari pembelajaran adalah membantu siswa agar mereka dapat belajar secara baik dan benar secara maksimal. Manajemen dalam hal ini berarti mengatur atau mengelola sesuatu hal agar menjadi baik. Hal ini sesuai dengan hadits, AnNawawi (1987: 17) ${ }^{9}$ yang diriwayatkan dari Ya'la Rasulullah bersabda: "Sesungguhnya mewajibkan kepada kita untuk berlaku ihsan dalam segala sesuatu." (HR. Bukhari: No. 6010).

Berdasarkan hadits di atas, pengawasan dalam Islam dilakukan untuk meluruskan yang bengkok, mengoreksi yang salah dan membenarkan yang hak. Pengawasan di dalam ajaran Islam, paling tidak terbagi kepada 2 (dua) hal: pertama, pengawasan yang berasal dari diri, yang bersumber dari tauhid dan keimanan kepada Allah SWT. Orang yang yakin bahwa Allah pasti mengawasi hamba-Nya, maka orang itu akan bertindak hati-hati. Ketika sendiri, dia yakin Allah yang kedua, dan ketika berdua dia yakin Allah yang ketiga. Allah SWT berfirman. ${ }^{10}$ : Artinya "Tidaklah kamu perhatikan, bahwa sesungguhnya Allah mengetahui apa yang ada di langit dan apa yang ada di bumi? Tiada pembicaraan rahasia antara tiga orang, melainkan Dia-lah yang keempatnya. Dan tiada (pembicaraan antara) empat melainkan Dia-lah yang kelimanya. Dan tiada (pembicaraan antara) lima orang, melainkan Dia-lah yang keenamnya. Dan tiada (pula) pembicaraan antara (jumlah) yang kurang dari itu atau lebih banyak, melainkan Dia

\footnotetext{
${ }^{9}$ An-Nawawi (1987: 17) yang diriwayatkan dari Ya'la

${ }^{10}$ (QS. Al-Mujadalah: 7). Tafsir Qur'an perkata Maghfirah Pustaka 2006
}

ada bersama mereka di manapun mereka berada. Kemudian Dia akan memberitakan kepada mereka pada hari kiamat apa yang telah mereka kerjakan. Sesungguhnya Allah Maha Mengetahui segala sesuatu”. (QS. Al-Mujadalah:7). Selain itu berdasarkan hadits yang diriwayatkan oleh Imam Thabrani bahwasanya Rasulullah SAW bersabda:" "Sesungguhnya Allah mencintai orang yang jika melakukan suatu pekerjaan, dilakukan secara itqan (tepat, terarah, dan tuntas) (HR. Thabrani).

Tujuan melakukan pengawasan, pengendalian dan koreksi adalah untuk mencegah seseorang jatuh terjerumus kepada sesuatu yang salah. Tujuan lainnya adalah agar kualitas kehidupan terus meningkat. Inilah yang dimaksud dengan tausiyah, dan bukan untuk menjatuhkan. Fungsi manajerial pengawasan adalah untuk mengukur dan mengkoreksi kerja bawahan untuk memastikan bahwa tujuan organisasi dan rencana yang didesain sedang dilaksanakan. Dalam konteks ini, implementasi syariah diwujudkan melalui tiga pilar pengawasan, yaitu:

a. Ketaqwaan individu, bahwa seluruh personel perusahaan dipastikan dan dibina agar menjadi manusia yang bertaqwa;

b. Pengawasan anggota, dalam suasana organisasi yang mencerminkan sebuah team maka proses keberlangsungan organisasi selalu akan mendapatkan pengawasan dari personelnya sesuai dengan arah yang telah ditetapkan;

c. Penerapan/supremasi aturan, organisasi ditegakkan dengan aturan main yang jelas dan transparan dan tidak bertentangan dengan syariah.

Ar-riqobah atau proses pengawasan merupakan kewajiban yang terus menerus

${ }^{11}$ (HR. Thabrani). Hadist Imam Thabroni Allah mencintai orang yang jika melakukan suatu pekerjaan, dilakukan secara itqan 
harus dilaksanakan, karena pengawasan merupakan pengecekan jalannya planning dalam organisasi guna menghindari kegagalan atau akibat yang lebih buruk. Mengenai faktor ini al-Qur'an memberikan konsepsi yang tegas agar hal yang bersifat merugikan tidak terjadi. Tekanan al-Qur'an lebih dahulu pada intropeksi, evaluasi diri pribadi sebagai pimpinan apakah sudah sejalan dengan pola dan tingkah berdasarkan planning dan program yang telah dirumuskan semula. Setidak-tidaknya menunjukkan sikap yangh simpatik dalm menjalankan tugas, selanjutnya mengadakan pengecekan atau memeriksa kerja anggotanya.

\section{Delapan Standar Nasional Pendidikan Menurut BSNP: ${ }^{12}$}

a. Standar Kompetensi Lulusan. Standar Kompetensi Lulusan untuk satuan pendidikan dasar dan menengah digunakan sebagai pedoman penilaian dalam menentukan kelulusan peserta didik. Standar Kompetensi Lulusan (SKL) tersebut meliputi standar kompetensi lulusan minimal satuan pendidikan dasar dan menengah, standar kompetensi lulusan minimal kelompok mata pelajaran, dan standar kompetensi lulusan minimal mata pelajaran.

b. Standar Isi. $^{13}$ Standar Isi mencakup lingkup materi minimal dan tingkat kompetensi minimal untuk mencapai kompetensi lulusan minimal pada

\footnotetext{
${ }^{12}$ Pelaksanaan Peraturan Menteri Pendidikan Nasional Nomor 22 tahun 2006 tentang standar Isi untuk satuan pendidikan Dasar dan Menengah dan Peraturan Menteri Pendidikan Nasional Nomor 23 Tahun 2006 Tentang Standar Kompetensi Lulusan untuk satuan pendidikan Dasar dan Menengah

${ }^{13}$ Pelaksanaan Peraturan Menteri Pendidikan Nasional Nomor 22 tahun 2006 tentang standar Isi untuk satuan pendidikan Dasar dan Menengah dan Peraturan Menteri Pendidikan Nasional Nomor 23 Tahun 2006 Tentang Standar Kompetensi Lulusan untuk satuan pendidikan Dasar dan Menengah
}

jenjang dan jenis pendidikan tertentu. Standar isi tersebut memuat kerangka dasar dan struktur kurikulum, beban belajar, kurikulum tingkat satuan pendidikan, dan kalender pendidikan.

c. Standar Proses. Proses pembelajaran pada satuan pendidikan diselenggarakan secara interaktif, inspiratif, menyenangkan, menantang, memotivasi peserta didik untuk berpartisipasi aktif, serta memberikan ruang yang cukup bagi prakarsa, kreativitas, dan kemandirian sesuai dengan bakat, minat, dan perkembangan fisik serta psikologis peserta didik. Selain itu, dalam proses pembelajaran pendidik memberikan keteladanan. Setiap satuan pendidikan melakukan perencanaan proses pembelajaran, pelaksanaan proses pembelajaran, penilaian hasil pembelajaran, dan pengawasan proses pembelajaran untuk terlaksananya proses pembelajaran yang efektif dan efisien.

d. Standar Pendidikan dan Tenaga Kependidikan. Pendidik harus memiliki kualifikasi akademik dan kompetensi sebagai agen pembelajaran, sehat jasmani dan rohani, serta memiliki kemampuan untuk mewujudkan tujuan pendidikan nasional. Kualifikasi akademik yang dimaksudkan di atas adalah tingkat pendidikan minimal yang harus dipenuhi oleh seorang pendidik yang dibuktikan dengan ijazah dan/atau sertifikat keahlian yang relevan sesuai ketentuan perundang-undangan yang berlaku. Kompetensi sebagai agen pembelajaran pada jenjang pendidikan dasar dan menengah serta pendidikan anak usia dini meliputi:

Kompetensi pedagogik;

Kompetensi kepribadian;

Kompetensi profesional; dan

Kompetensi sosial. 
e. Standar Sarana dan Prasarana. Setiap satuan pendidikan wajib memiliki sarana yang meliputi perabot, peralatan pendidikan, media pendidikan, buku dan sumber belajar lainnya, bahan habis pakai, serta perlengkapan lain yang diperlukan untuk menunjang proses pembelajaran yang teratur dan berkelanjutan. Setiap satuan pendidikan wajib memiliki prasarana yang meliputi lahan, ruang kelas, ruang pimpinan satuan pendidikan, ruang pendidik, ruang tata usaha, ruang perpustakaan, ruang laboratorium, ruang bengkel kerja, ruang unit produksi, ruang kantin, instalasi daya dan jasa, tempat berolahraga, tempat beribadah, tempat bermain, tempat berkreasi, dan ruang/tempat lain yang diperlukan untuk menunjang proses pembelajaran yang teratur dan berkelanjutan.

f. Standar Pengelolaan ${ }^{14}$. Standar Pengelolaan terdiri dari 3 (tiga) bagian, yakni standar pengelolaan oleh satuan pendidikan, standar pengelolaan oleh Pemerintah Daerah dan standar pengelolaan oleh Pemerintah.

g. Standar Pembiayaan Pendidikan. Pembiayaan pendidikan terdiri atas biaya investasi, biaya operasi, dan biaya personal. Biaya investasi satuan pendidikan sebagaimana dimaksud di atas meliputi biaya penyediaan sarana dan prasarana, pengembangan sumberdaya manusia, dan modal kerja tetap. Biaya personal sebagaimana dimaksud pada di atas meliputi biaya pendidikan yang harus dikeluarkan oleh peserta didik untuk bisa mengikuti proses pembelajaran secara teratur dan berkelanjutan.

\footnotetext{
${ }^{14}$ Pelaksanaan Peraturan Menteri Pendidikan Nasional Nomor 22 tahun 2006 tentang standar Isi untuk satuan pendidikan Dasar dan Menengah dan Peraturan Menteri Pendidikan Nasional Nomor 23 Tahun 2006 Tentang Standar Kompetensi Lulusan untuk satuan pendidikan Dasar dan Menengah
}

h. Standar Penilaian Pendidikan. ${ }^{15}$ Penilaian pendidikan pada jenjang pendidikan dasar dan menengah terdiri atas:

Penilaian hasil belajar oleh pendidik;

Penilaian hasil belajar oleh satuan pendidikan; dan

Penilaian hasil belajar oleh Pemerintah. Penilaian pendidikan pada jenjang pendidikan tinggi terdiri atas:

Penilaian hasil belajar oleh pendidik; dan Penilaian hasil belajar oleh satuan pendidikan tinggi.

\section{Fungsi dan Tujuan Standar Nasional Pendidikan:}

a. Standar Nasional Pendidikan berfungsi sebagai dasar dalam perencanaan, pelaksanaan, dan pengawasan pendidikan dalam rangka mewujudkan pendidikan nasional yang bermutu

b. Standar Nasional Pendidikan bertujuan menjamin mutu pendidikan nasional dalam rangka mencerdaskan kehidupan bangsa dan membentuk watak serta peradaban bangsa yang bermartabat.

c. Standar Nasional Pendidikan disempurnakan secara terencana, terarah, dan berkelanjutan sesuai dengan tuntutan perubahan kehidupan lokal, nasional, dan global.

\section{Pelaksana Akuntabilitas Pendidikan \\ Menurut Made Pidarta $(1988)^{16}$ menyebutkan bahwa pelaksanaan akuntabilitas ditekankan pada guru,}

\footnotetext{
${ }^{15}$ Pelaksanaan Peraturan Menteri Pendidikan Nasional Nomor 22 tahun 2006 tentang standar Isi untuk satuan pendidikan Dasar dan Menengah dan Peraturan Menteri Pendidikan Nasional Nomor 23 Tahun 2006 Tentang Standar Kompetensi Lulusan untuk satuan pendidikan Dasar dan Menengah

${ }^{16}$ Insentif terhadap pelaksana sudah ditentukan secara pasti. D. Pelaksana Akuntabilitas Pendidikan Made Pidarta (1988) menyebutkan bahwa pelaksanaan akuntabilitas ditekankan pada guru, administrator, orang tua siswa, masyarakat serta orang-orang luar lainnya. Di dalam perencanaan participatory.
} 
administrator, orang tua siswa, masyarakat serta orang-orang luar lainnya. Di dalam perencanaan participatory, yaitu perencanaan yang menekankan sifat lokal atau desentralisasi, akuntabilitas ditujukan pada sejumlah personil sebagai berikut:

a. Manajer/administrator/ketua lembaga, sesuai dengan fungsinya sebagai manajer.

Ketua perencana, yang dianggap paling bertanggungjawab atas keberhasilan perencanaan. Ketua perencana adalah dekan, rektor, kepala sekolah, atau pimpinan unit kerja lainnya.

b. Para anggota perencana, mereka dituntut memiliki akuntabilitas karena mereka bekerja mewujudkan konsep perencanaan dan mengendalikan implementasinya di lapangan.

c. Konsultan, para ahli perencana yang menjadi konsultan.

d. Para pemberi data, harus memiliki performan yang kuat mengingat tugasnya memberikan dan meng informasikan data yang selalu siap dan akurat.

Akuntabilitas tidak saja menyangkut proses pembelajaran, tetapi juga menyangkut pengelolaan keuangan, dan kualitas output. Akuntabilitas keuangan dapat diukur dari semakin kecilnya penyimpangan dalam pengelolaan keuangan sekolah. Baik sumber-sumber penerimaan, besar kecilnya penerimaan, maupun peruntukkannya dapat di pertanggungjawab kan oleh pengelola. Pengelola keuangan yang bertanggung jawab akan mendapat kepercayaan dari warga sekolah dan masyarakat. Sebaliknya pengelola yang melakukan praktek korupsi tidak akan dipercaya.

Akuntabilitas tidak saja menyangkut sistem tetapi juga menyangkut moral individu. Jadi, moral individu yang baik dan didukung oleh sistem yang baik akan menjamin pengelolaan keuangan yang bersih, dan jauh dari praktek korupsi.
Akuntabilitas juga semakin memiliki arti, ketika sekolah mampu mempertanggungjawabkan mutu outputnya terhadap publik. Sekolah yang mampu mempertanggungjawabkan kualitas outputnya terhadap publik, mencerminkan sekolah yang memiliki tingkat efektivitas output tinggi. Dan sekolah yang memiliki tingkat efektivitas outputnya tinggi, akan meningkatkan efisiensi eksternal. Bagaimana sekolah mampu mem pertanggung jawab kan kewenangan yang diberikan kepada publik, tentu menjadi tantangan tanggung jawab sekolah.

Menurut Fasli Jalal dan Dedi Supriadi (2001:88) ${ }^{17}$ menyatakan di Indonesia banyak instituasi pendidikan yang lemah dan tidak akuntabel. Menurut Rita Headington. ${ }^{18}$ ada tiga dimensi yang terkandung dalam akuntabilitas, yaitu; Moral,Hukum, dan Keuangan. Ketiganya menuntut tanggung jawab dari sekolah untuk mewujudkannya, tidak saja bagi publik tetapi pertama-tama harus dimulai bagi warga sekolah itu sendiri, misalnya akuntabilitas dari guru. Secara moral maupun secara formal (aturan) guru memiliki tanggung jawab bagi siswa maupun orang tua siswa untuk mewujudkan proses pembelajaran yang baik. Tidak saja guru tetapi juga badanbadan yang terkait dengan pendidikan.

\section{Langkah-Langkah Akuntabilitas Pendidikan}

Menurut ${ }^{19}$ Made Pidarta (1988) merumuskan langkah-langkah yang harus

\footnotetext{
${ }^{17}$ Fasli Jalal dan Dedi Supriadi (2001: 88) menyatakan di Indonesia banyak instituasi pendidikan yang lemah dan tidak akuntabel

${ }^{18}$ Rita Headington ada tiga dimensi yang terkandung dalam akuntabilitas, yaitu ; Moral, Hukum, dan Keuangan.

${ }^{19}$ Made Pidarta (1988) merumuskan langkahlangkah yang harus di tempuh untuk menentukan akuntabilitas dalam melaksanakan tugas-tugas pendidikan, sebagai berikut: 1. Menentukan tujuan
} 
di tempuh untuk menentukan akuntabilitas dalam melaksanakan tugas-tugas pendidikan, sebagai berikut:

a. Menentukan tujuan program yang dikerjakan, dalam perencanaan disebut misi atau tujuan perencanaan.

b. Program dioperasionalkan sehingga menimbulkan tujuan-tujuan yang spesifik.

c. Menggambarkan kondisi tempat bekerja.

d. Menentukan otoritas atau kewenangan petugas pendidikan.

e. Menentukan pelaksana yang akan mengerjakan program/tugas. Ia penanggungjawab program, menurut konsep akuntabilitas ia adalah orang yang dikontrak.

f. Membuat kriteria performan pelaksana yang dikontrak secara jelas, sebab hakekatnya yang dikontrak adalah performan ini.

g. Menentukan pengukur yang bersifat bebas, yaitu orang-orang yang tidak terlibat dalam pelaksanaan program tersebut.

h. Pengukuran dilakukan sesuai dengan syarat pengukuran umum yang berlaku, yaitu secara insidental, berkala dan

i. Hasil pengukuran dilaporkan kepada orang yang berkaitan.

\section{Faktor yang Mempengaruhi Akuntabilitas Pendidikan}

Faktor yang mempengaruhi akuntabilitas terletak pada dua hal yaitu ; faktor sistem dan faktor orang. Sistem menyangkut aturan-aturan dan tradisi organisasi. Sedangkan faktor orang menyangkut motivasi, persepsi dan nilainilai yang dianutnya yang mempengaruhi kemampuannya akuntabilitas.

H. Upaya Peningkatan Akuntabilitas Pendidikan

program yang dikerjakan, dalam perencanaan disebut misi

Menurut $^{20}$ Slamet (2005:6) ada delapan hal yang harus dikerjakan oleh sekolah untuk peningkatan akuntabilitas:

a. Sekolah harus menyusun aturan main tentang sistem akuntabilitas termasuk mekanisme pertanggung jawaban.

b. Sekolah perlu menyusun pedoman tingkah laku dan sistem pemantauan kinerja penyelenggara sekolah dan sistem pengawasan dengan sanksi yang jelas dan tegas.

c. Sekolah menyusun rencana pengembangan sekolah dan menyampaikan kepada publik/ stakeholders di awal setiap tahun anggaran

d. Menyusun indikator yang jelas tentang pengukuran kinerja sekolah dan disampaikan kepada stakeholders.

e. Melakukan pengukuran pencapaian kinerja pelayanan pendidikan dan menyampaikan hasilnya kepada publik/ stakeholders diakhir tahun.

f. Memberikan tanggapan terhadap pertanyaan dan pengaduan publik.

g. Menyediakan informasi kegiatan sekolah kepada publik yang akan memperoleh pelayanan pendidikan.

h. Memperbaharui rencana kinerja yang baru sebagai kesepakatan komitmen baru.

Kedelapan upaya di atas, semuanya bertumpu pada kemampuan dan kemauan sekolah untuk mewujudkannya. Jika sekolah mengetahui sumber dayanya, maka dapat lebih mudah digerakkan untuk mewujudkan dan meningkatkan akuntabilitas. Sekolah dapat melibatkan stakeholders untuk menyusun dan

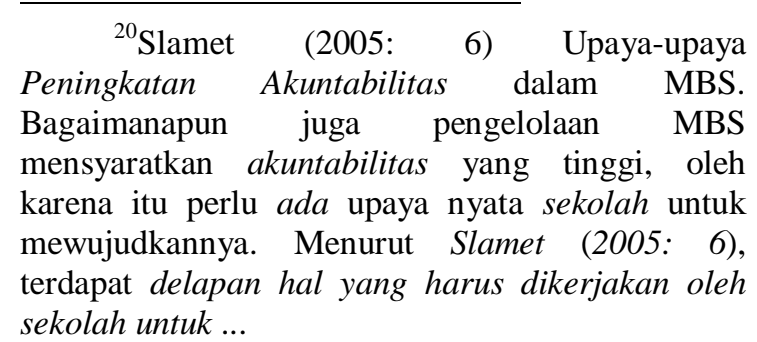


memperbaharui sistem yang dianggap tidak dapat menjamin terwujudnya akuntabilitas di sekolah. Komite sekolah, orang tua siswa, kelompok profesi, dan pemerintah dapat dilibatkan untuk melaksanakannya. Dengan begitu stakeholders sejak awal tahu dan merasa memiliki akan sistem yang ada.

Untuk mengukur berhasil tidaknya akuntabilitas dalam manajemen berbasis sekolah, dapat dilihat pada beberapa hal;

Menurut $^{21}$ Slamet (2005:7), Beberapa indikator keberhasilan akuntabilitas adalah:

1. Meningkatnya kepercayaan dan kepuasan publik terhadap.

2. Tumbuhnya kesadaran publik tentang hak untuk menilai terhadap penyelenggaraan pendidikan di sekolah, dan

3. Meningkatnya kesesuaian kegiatankegiatan sekolah dengan nilai dan norma yang berkembang di masyarakat.

Ketiga indikator di atas dapat dipakai oleh sekolah untuk mengukur apakah akuntabilitas manajemen sekolah telah mencapai hasil sebagaimana yang dikehendaki. Tidak saja publik merasa puas, tetapi sekolah akan mengalami peningkatan dalam banyak hal.

\section{Jenis Akuntabilitas pada Pemimpin}

Menurut $^{22}$ Bruce Stone, O.P
Dwivedi, dan Joseph G. Jabbra (1995) menyoroti beberapa tipe dari akuntabilitas:

a. Akuntabilitas Moral. tanggung jawab moral secara pribadi maupun kolektif.

${ }^{21}$ Slamet (2005: 7), Beberapa indikator keberhasilan akuntabilitas adalah: 1. Meningkatnya kepercayaan dan kepuasan publik terhadap sekolah.

${ }^{22}$ Bruce Stone, O.P Dwivedi, dan Joseph G. Jabbra (1995) Pengertian Akuntabilitas (terdapat 8 jenis akuntabilitas yang umumnya berkaitan dengan moral, administratif, politik, manajerial, pasar, hukum dan peradilan, hubungan dengan konstituen serta profesional. a. Akuntabilitas Politik Akuntabilitas politik )
Akuntabilitas diukur oleh peraturan yang berlaku dengan apa yang diyakini kebenarannya.

b. Akuntabilitas Politik. Akuntabilitas politik adalah akuntabilitas dari pemangku kepemimpinan yaitu pemerintah, sebagai pelayan masyarakat, dan lembaga legslatif DPR, MPR. ${ }^{23}$

c. Akuntabilitas Administratif. Yaitu melayani masyarakat secara administrasi pemerintahan untuk tetap akuntabel, dalam berbagai mekanisme dan berbagai peraturan dan norma.

d. Akuntabilitas Pasar (Share markett). desentralisasi dan privatisasi kepada pihak pemerintah, dan berbagai bentuk pelayanan yang tersedia lebih terfokus kepada kebutuhan konsumen (customer-driven) masyarakat.

e. Akuntabilitas dalam berbagai hubungan konstituen. Lembaga tertentu maka, institusi yang ada diluar sektor publik yang mewakili berbagai kepentingan masyarakat.

f. Akuntabilitas Manajerial. terpusat pada manajerial suatu organisasi, efisiensi dan efektivitas penggunaan dana perusahaan, yang berupa dana, sumber daya manusia, berbagai peralatan lainnya, Akuntabilitas ini juga pada kinerja manajer atau pengawas dalam menangani masalah yang ada, menetapkan suatu proses yang berkelanjutan, perencaaan dan penganggaran, memberikan pelayan yang terbaik.

g. Akuntabilitas Professional. diperuntukkan dengan cara menetapkan standar profesi dan berbagai kode etik. Dalam

${ }^{23}$ Gedung DPR/MPR RI dirancang oleh Soejoedi Wirjoatmodjo dan ditetapkan serta disahkan oleh Presiden Soekarno pada tanggal 22 Februari 1965. Tinggi bangunannya 100 meter dan memiliki 24 lantai dengan total luas bangunan mancapai 80.000 meter persegi. Awalnya, gedung megah ini bukan difungsikan sebagai . 
melaksanakan kegiatannya tetap pada jalur norma-norma dan standar profesi tersebut.

h. Akuntabilitas Legal/Yudisial. pada aspek hukum, dimana pelaksanaan hukum harus disesuaikan dengan produk dan jasa hukum yang berlaku pada masyarakat dan mengacu pada aturan pemerintah.

\section{Kepemimpinan Yang Baik}

a. Aspek transparansi pada pengelola lembaga pendidikan, terbuka dan jujur mengenai semua tindakan/kegiatan, serta alasan-alasannya yang dilakukan dan komitmen terhadap dampak tindakan tersebut pada masyarakat dan lingkungannya.

b. Aspek respon (responsive), Tingkat respon terhadap lembaga pada berbagai hal yang menjadi perhatian/ keinginan dari para stake holder yang memiliki kemampuan untuk mempengaruhi, kegiatan pada lembaga tersebut.

c. Aspek kepatuhan (compliant) Kegiatan pada lembaga harus sesuai, relevan dengan berbagai standar dan peraturan yang telah dimandatkan.

\section{Kesimpulan}

Kepemimpinan pada pendidikan sebagai pemberi keputusan berbagai kebijakan maupun berbagai bentuk dalam pelaksanaannya, harus meresfon dalam hal akuntabilitas yang berdasar filosofi Agama. Akreditasi dan berbagai upaya, peraturan untuk mengawasi, mendorong dalam pelaksanaan kependidikan, akuntabilitas pemerintah dan lembaga pendidikan yang berkualitas.Tanggung jawab kepada masyarakat dan Tanggung jawab kepada Allah sebagai manifestasi dari implementasi terhadap agama yang dianutnya, dalam memenuhi tuntutan masyarakat akan kepuasan terhadap kualitas pendidikan, dan transparansi dalam pengeloaannya, yang berkaitan dengan pendanaan, kesejahteraan pada tenaga kependidikan, dan lembaga kependidikan.

\section{DAFTAR PUSTAKA}

Sanusi, Ahmad, Iriantara, Yosal Editor; 2016. Pendidikan Untuk Kearifan, Mempertimbangkan Kembali Sistem Nilai, Belajar, dan Kecerdasan; Bandung, Penerbit Nuansa.

Darmaningtyas, 2005, Pendidikan Rusakrusakan, Yogyakarta: LKIS Group

Fatah, Nanang, 2004, Konsep Manajemen Berbasis Sekolah dan Dewan Sekolah, Bandung: Pustaka Bani Qurais.

Pidarta, Made. 2006, Otonomi Pendidikan, Kebijakan Otonomi Daerah dan Implikasinya terhadap Penyelenggaraan Pendidikan; Jakarta: Divisi Buku Perguruan Tinggi, Raja Grafindo Persada.

Sirozi, M. 2005, Pendidikan Politik, Jakarta: Raja Grafindo Persada.

Darmaningtyas, 2005. Pendidikan Rusakrusakan, Yogyakarta: LKIS

Made, pinarta, 2006. Otonomi Pendidikan Kebijakan Otonomi Daerah dan Implikasinya terhadap Penyelenggaraan Pendidikan, Jakarta: Divisi Buku Perguruan Tinggi, Raja Grafindo Persada

M. Sirozi, Politik Pendidikan, 2005. Jakarta: PT. Raja Grafindo Persada. 